\title{
Increased Anxiety 3 Months after Brief Exposure to MDMA ('Ecstasy') in Rats: Association with Altered 5-HT Transporter and Receptor Density
}

\author{
lain S McGregor*,', Kelly J Clemens', Geoffrey Van der Plasse', Kong M Li², Glenn E Hunt ${ }^{3}$, Feng Chen ${ }^{4}$, \\ and Andrew J Lawrence 4 \\ 'School of Psychology, University of Sydney, NSW 2006, Australia; '2Department of Pharmacology, University of Sydney, NSW 2006, Australia; \\ ${ }^{3}$ Department of Psychological Medicine, University of Sydney, Concord Hospital, NSW 2139, Australia; ${ }^{4}$ Department of Pharmacology, Monash \\ University, Clayton, VIC 3800, Australia
}

\begin{abstract}
Male Wistar rats were treated with 3,4-methylenedioxymethamphetamine (MDMA, 'Ecstasy') using either a high dose $(4 \times 5 \mathrm{mg} / \mathrm{kg}$ over $4 \mathrm{~h}$ ) or low dose $(1 \times 5 \mathrm{mg} / \mathrm{kg}$ over $4 \mathrm{~h})$ regimen on each of 2 consecutive days. After 10 weeks, rats were tested in the social interaction and emergence tests of anxiety. Rats previously given either of the MDMA dose regimens were significantly more anxious on both tests. After behavioral testing, and 3 months after the MDMA treatment, the rats were killed and their brains examined. Rats given the high-, but not the low-, dose MDMA treatment regimen exhibited significant loss of 5-hydroxytryptamine (5-HT) and 5-HIAA in the amygdala hippocampus, striatum, and cortex. Quantitative autoradiography showed loss of SERT binding in cortical, hippocampal, thalamic, and hypothalamic sites with the high-dose MDMA regime, while low-dose MDMA only produced significant loss in the medial hypothalamus. Neither high- nor low-dose MDMA affected $5 \mathrm{HT}_{\text {IA }}$ receptor density. High-dose MDMA increased $5 \mathrm{HT}_{\mathrm{IB}}$ receptor density in the nucleus accumbens and lateral septum but decreased binding in the globus pallidus, insular cortex and medial thalamus. Low-dose MDMA decreased $5 \mathrm{HT}_{\mathrm{IB}}$ receptor density in the hippocampus, globus pallidus, and medial thalamus. High-dose MDMA caused dramatic decreases in cortical, striatal, thalamic, and hypothalamic $5 \mathrm{HT}_{2 \mathrm{~A}} \mathrm{I}_{2 \mathrm{C}}$ receptor density, while low-dose MDMA tended to produce similar effects but only significantly in the piriform cortex. These data suggest that even brief, relatively low-dose MDMA exposure can produce significant, long-term changes in 5-HT receptor and transporter function and associated emotional behavior. Interestingly, long-term 5HT depletion may not be necessary to produce lasting effects on anxiety-like behavior after low-dose MDMA.

Neuropsychopharmacology (2003) 28, 1472-1484, advance online publication, 16 April 2003; doi: I0.1038/sj.npp.1300। 85
\end{abstract}

Keywords: MDMA; ecstasy; anxiety; serotonin; 5-HT; autoradiography

\section{INTRODUCTION}

MDMA (3,4-methylenedioxymethamphetamine, 'Ecstasy') is a drug with unique empathogenic properties and one of the most popular illicit recreational drugs in the world. For more than 15 years it has been known that MDMA and several closely related amphetamine derivatives produce depletion of the neurotransmitter 5-hydroxytryptamine (5HT) in the brains of laboratory animals (Battaglia et al, 1987; Commins et al, 1987; Ricaurte et al, 1985). This loss of 5-HT reflects a primary toxic effect of these drugs on 5-HT axons leading to loss of 5-HT terminals, but not cell bodies

* Correspondence: Dr IS McGregor, School of Psychology, University of Sydney, A19, NSW 2006, Australia, Tel: +61 29351 3571, Fax: +61 2935 I 8023, E-mail address: iain@psych.usyd.edu.au

Received 23 October 2002; revised 04 February 2003; accepted 10 February 2003

Online publication: 26 February 2003 at http://www.acnp.org/citations/ Npp022602388/default.pdf
(Callahan et al, 2001; Scallet et al, 1988). There is controversy, however, over whether similar effects are seen in humans who use MDMA. Brain imaging studies suggesting loss of 5-HT innervation in human MDMA users (McCann et al, 1998; Semple et al, 1999) have been subjected to some recent criticism (Kish, 2002).

Nonetheless, there is growing clinical evidence that human MDMA users, particularly heavy users, are more prone to a variety of psychological problems, including anxiety, depression, and memory impairment (Morgan, 2000; Parrott, 2001; Schifano et al, 1998; Topp et al, 1999). Given the important role of 5-HT in cognition and mood, these clinical manifestations are consistent with presumed 5-HT depletion (Boot et al, 2000). These clinical effects have been mirrored in recent preclinical studies from our laboratory where Wistar rats briefly exposed to MDMA were shown to have long-term increases in anxiety-like behavior in the social interaction, elevated plus maze and emergence tests 1-3 months post-MDMA 
(Gurtman et al, 2002; Morley et al, 2001). MDMA-treated rats also displayed inferior memory in an object recognition test (Morley et al, 2001). Post-mortem neurochemical analysis showed that these rats had approximately $40-50 \%$ loss of 5-HT in cortex, hippocampus, amygdala, and striatum (Gurtman et al, 2002).

Recent work has also shown that MDMA causes longterm decreases in social interaction in Lister rats, but in the absence of significant depletion in brain 5-HT (Fone et al, 2002). Long-term increases in anxiety-like behavior have also been seen in rats given relatively modest doses of MDMA ( $5 \mathrm{mg} / \mathrm{kg}$ on 2 consecutive days) that might not be expected to produce 5-HT depletion (Morley et al, 2001). Taken together, these results raise the possibility that MDMA may produce long-term emotional and behavioral effects that are not necessarily linked to a long-term loss of 5-HT. Rather it may be other neural adaptations to MDMA that underlie the long-term effects of the drug (Green and McGregor, 2002).

A variety of 5-HT receptor subtypes are known to play a role in anxiety-like behavior, for example $5-\mathrm{HT}_{1 \mathrm{~A}}, 5-\mathrm{HT}_{1 \mathrm{~B}}$, 5- $\mathrm{HT}_{2 \mathrm{C}}$, and $5-\mathrm{HT}_{3}$ (Griebel, 1995). The 5-HT transporter (SERT) is also known to play an important role in anxiety, and is the key target for the antidepressant drugs commonly used to treat anxiety disorders in humans (Lesch et al, 1996; Rausch et al, 2001). This suggests that changes in anxietylike behavior in rats given MDMA may be related to changes at the 5-HT receptor and/or transporter level. High-dose MDMA produces loss of SERT binding sites in rats (Battaglia et al, 1991, 1987; Lew et al, 1996) and primates (Jagust et al, 1996; Scheffel et al, 1998) while brain imaging studies suggest a similar loss of SERT in human MDMA users (McCann et al, 1998; Semple et al, 1999).

A small number of studies have also tracked long-term changes in specific 5-HT receptors following MDMA administration. There have been reports that $5-\mathrm{HT}_{1 \mathrm{~A}}$ receptor density in the forebrain may be increased with MDMA treatment (Aguirre et al, 1998, 1995). Transient upregulation of $5-\mathrm{HT}_{1 \mathrm{~B}}$ receptors has also been reported after high-dose MDMA (Sexton et al, 1999). Similarly, a short-term decline in $5-\mathrm{HT}_{2 \mathrm{~A}}$ and/or $5-\mathrm{HT}_{2 \mathrm{C}}$ receptors has been shown following MDMA treatment (Reneman et al, 2002b; Scheffel et al, 1992).

In the present study, we administered rats either a highor low-dose MDMA regime over 2 successive days. Ten weeks later, we examined anxiety-like behavior in the social interaction and emergence tests. Rats were then killed and their brains assayed for 5-HT using HPLC, and for density of SERT, the dopamine transporter (DAT), 5- $\mathrm{HT}_{1 \mathrm{~A}}$ receptors, $5-\mathrm{HT}_{1 \mathrm{~B}}$ receptors and $5-\mathrm{HT}_{2 \mathrm{~A} / 2 \mathrm{C}}$ receptors using quantitative autoradiography. It was predicted that rats given the low-dose MDMA treatment may not show 5-HT depletion but might show marked alterations in 5-HT transporters or receptors, changes that could conceivably underlie any increased anxiety-like behavior seen.

\section{METHODS}

\section{Subjects}

The subjects were 36 inbred male albino Wistar rats (Concord Hospital breeding facility) aged 3 months at the beginning of the experiment and weighing $374 \pm 17 \mathrm{~g}$. The rats were housed in groups of 6-8 per cage for the duration of the experiment with food and water freely available. The temperature in the colony room was controlled at $22^{\circ} \mathrm{C}$ and a $12 \mathrm{~h}$ reverse light cycle was in operation. All behavioral testing was conducted during the dark cycle. All experimentation was approved by the University of Sydney animal ethics committee and was carried out in accordance with the National Institutes of Health Guide for the Care and Use of Laboratory Animals.

\section{Experimental Procedures}

Drug. (+ /-)3,4-Methylenedioxymethamphetamine was supplied by the Australian Government Analytical Laboratories (Pymble, NSW). It was diluted in $0.9 \%$ saline and injected i.p. at a dose of $5 \mathrm{mg} / \mathrm{kg}$ at a volume of $1 \mathrm{ml} / \mathrm{kg}$.

Drug administration. During the drug administration period, individual rats were placed in standard operant chambers $\left(30 \times 50 \times 25.5 \mathrm{~cm}^{3}\right)$ with aluminium side and back walls, a Perspex front wall, and a metal grid floor. The chambers were placed inside wooden sound attenuation boxes. The ambient temperature in the room in which the chambers were located was maintained at $28 \pm 1.0^{\circ} \mathrm{C}$. High ambient temperatures are thought to promote the neurotoxic effects of MDMA (Broening et al, 1995; Malberg et al, 1996; Malberg and Seiden, 1998).

The drug administration session lasted for $4 \mathrm{~h}$. Rats were given an initial dose of MDMA or vehicle and placed in the chambers. Each hour, rats were briefly removed from the test chambers to administer their next injection of MDMA or vehicle.

Rats in the high-dose MDMA group $(n=12)$ were given a $5 \mathrm{mg} / \mathrm{kg}$ i.p. dose of MDMA every hour for $4 \mathrm{~h}$ on each of 2 consecutive days to give a cumulative total dose of $40 \mathrm{mg} / \mathrm{kg}$ (20 mg/kg/day). This dose regime is intended to simulate a weekend of heavy MDMA use in a human user, given that the typical self-administered human dose is 1-2 tablets, equivalent to 1-4 mg/kg MDMA (Boot et al, 2000). The halflife of MDMA is approximately $2.2 \mathrm{~h}$ in the rat (Fitzgerald et al, 1990) so that the $4 \times 5 \mathrm{mg} / \mathrm{kg}$ regime may produce peak MDMA concentrations similar to that produced by a single $15 \mathrm{mg} / \mathrm{kg}$ injection of MDMA.

Rats in the low-dose MDMA group $(n=12)$ received a single $5 \mathrm{mg} / \mathrm{kg}$ i.p. injection of MDMA, intended to simulate the more typical human use of 1-2 tablets of MDMA (Boot et al, 2000). The single MDMA injection was followed by three injections of saline every hour over $4 \mathrm{~h}$ on each of 2 consecutive days to give a cumulative total dose of $10 \mathrm{mg} / \mathrm{kg}$ $(5 \mathrm{mg} / \mathrm{kg} /$ day). Rats in the vehicle group received an injection of saline every hour for $4 \mathrm{~h}$ on each of the 2 days. Each treatment condition was equally represented within the home cages.

This regime of drug administration has been used several times in our laboratory and is known to produce a robust hyperthermia and hyperactivity in rats given the high-dose MDMA treatment but no significant hyperthermia or hyperactivity in rats in the low-dose MDMA treatment (Gurtman et al, 2002; Morley et al, 2001). The high-dose regime is known to produce long-term effects on anxiety as well as substantial, lasting 5-HT depletion (Gurtman et al, 
2002; Morley et al, 2001). The low-dose regime produces alterations in anxiety-like behavior (Morley et al, 2001) but effects on 5-HT have yet to be determined.

Following the $4 \mathrm{~h}$ drug administration sessions, rats were returned to their home cages in the animal colony.

Social interaction test. At 10 weeks following drug administration, pairs of rats were assessed in the social interaction test. Testing occurred in a square clear Perspex box $\left(52 \times 52 \times 40 \mathrm{~cm}^{3}\right)$ dimly lit with red light $(40 \mathrm{~W})$. A miniature video camera was placed vertically above the box. The camera was connected to a video recorder and monitor in a neighbouring room where the interactions of the rats were recorded onto videotape. The experimenter remained outside the test room during testing and the test arena was wiped down with $10 \%$ ethanol in between each test session.

Testing was performed across 2 consecutive days, with each rat tested with a different partner on each of the 2 days. Partners were selected so as to be of approximately equal body weight and from the same treatment condition (highdose MDMA, low-dose MDMA, or vehicle) but from a different home cage. Data for a total of 12 pairs from each condition were obtained.

Each social interaction session lasted for $10 \mathrm{~min}$. The total duration of social interaction and the number of interactions during this $10 \mathrm{~min}$ period was scored from video by an observer using ODLog software (www.macropodsoftware.com). Behaviors that were recorded as social interaction included sniffing, adjacent lying, following, crawling over/under, and mutual grooming (Gurtman et al, 2002; Morley et al, 2001).

Emergence test. At 1 week after the social interaction test, rats were tested in the emergence test. The apparatus consists of a white Perspex-walled rectangular arena $\left(96 \times 100 \times 40 \mathrm{~cm}^{3}\right)$ with a black wooden hide box $\left(24 \times 40 \times 15 \mathrm{~cm}^{3}\right)$ placed in the top left corner of the arena. The open part of the arena was illuminated with red light $(40 \mathrm{~W})$ and a video camera was mounted above the arena and connected to a video recorder.

Rats were initially placed inside the wooden hide box (which had a hinged lid through which the rat could be placed inside the box). Testing continued for $5 \mathrm{~min}$, during which time the experimenter remained outside the test room.

Subsequent video analysis by an experimenter blind to group assignment scored the latency of rats to emerge from the hide box and the duration of time spent in the open field. 'Risk assessment' behavior was also scored, which refers to the time rats spent with their head poking out of the hide box but with the majority of the body remaining inside the box. Analysis was accomplished using ODLog data logging software from Macropod software (www.macropodsoftware.com).

After each test session the apparatus was thoroughly wiped down with a damp cloth containing $10 \%$ ethanol.

Neurochemical analysis. At 12 weeks following MDMA or vehicle treatment, 18 of the 36 rats used in the study ( $n=6$ per group) were decapitated using a guillotine, and their brains rapidly removed for neurochemical analysis. Five regions of interest were manually dissected out and frozen over dry ice using a method derived from that of Harkin et al (2001). Samples from the olfactory bulb, prefrontal cortex, striatum, hippocampus, and amygdala were individually placed in centrifuge tubes and stored in a freezer at $-80^{\circ} \mathrm{C}$ until assayed.

Tissue samples were weighed and then homogenized with a $500 \mu \mathrm{l}$ ice-cold solution of $0.2 \mathrm{M}$ perchloric acid containing $0.1 \%$ cysteine and $200 \mathrm{nmol} / \mathrm{l}$ of internal standard 5hydroxy- $\mathrm{N}$-methyltryptamine (5-HMeT). The homogenate was centrifuged at $15000 \mathrm{~g}$ for $10 \mathrm{~min}$ at $4^{\circ} \mathrm{C}$ and a $20 \mu \mathrm{l}$ aliquot of the resulting supernatant fluid was then analyzed for biogenic amines by high-performance liquid chromatography (HPLC) with electrochemical detection as described previously (Gurtman et al, 2002; Schworer et al, 1987).

Briefly, the GBC HPLC system (Melbourne, Australia) comprised an LC 1610 auto-injector, an LC 1150 multisolvent delivery pump, an LC 1210 electrochemical detector (ECD), and WinChrom data management software. The mobile phase consisted of $0.1 \mathrm{~mol} / \mathrm{l}$ phosphate buffer $(\mathrm{pH}$ 3.0), PIC B-8 octane sulfonic acid (Waters, Australia) $0.74 \mathrm{mmol} / \mathrm{l}$, sodium EDTA $(0.3 \mathrm{mmol} / \mathrm{l})$, and methanol $(12 \% \mathrm{v} / \mathrm{v})$. The flow rate was maintained at $1 \mathrm{ml} / \mathrm{min}$. Dopamine, 5-HIAA, 5-HT, and 5-HMeT were separated by a Merck LiChrospher 100 RP-18 reversed phase column. Quantification was achieved via ECD equipped with a glassy carbon working electrode set at a potential of $+0.75 \mathrm{~V}$ versus an $\mathrm{Ag} / \mathrm{AgCl}$ reference electrode. The calibration curve of each standard was obtained by the concentration versus the area ratio of the standard and internal standard.

Quantitative autoradiography. Also at 12 weeks following MDMA or vehicle treatment, the remaining 18 of the 36 rats were killed by decapitation, and their brains removed and rapidly frozen over dry ice, and then stored at $-80^{\circ} \mathrm{C}$. Coronal sections $(14 \mu \mathrm{m})$ were cut posterior to anterior on a Leica cryostat at the level of the dorsal raphe (AP $-8.00 \mathrm{~mm}$ from bregma), caudal amygdala $(-3.60)$, rostral amygdala $(-2.30)$, and nucleus accumbens $(+1.20)$. Sections were thaw mounted on gelatin/chrome alum-coated sides (two sections per slide), air dried, and then stored at $-80^{\circ} \mathrm{C}$ until required. In all cases, at least four sections/rat/ region were analyzed for each binding site, and at least two sections/rat/region were utilized to define nonspecific binding.

Serotonin and DAT. Binding of $\left[{ }^{125} \mathrm{I}\right] \mathrm{RTI}-55$ (Lew et al, 1996) was used to assess binding density for both the DAT and serotonin transporter (SERT). DAT binding was carried out at the level of the nucleus accumbens only, while SERT binding was carried out at all levels. Sections were allowed to defrost, and then preincubated for $30 \mathrm{~min}$ in phosphate buffer $\left(10 \mathrm{mM} \mathrm{NaH} \mathrm{PO}_{4}, 0.1 \mathrm{M}\right.$ sucrose, $\mathrm{pH}$ 7.4) at room temperature. DAT binding was defined with $50 \mathrm{pM}\left[{ }^{125} \mathrm{I}\right]$ RTI-55 in the presence of $50 \mathrm{nM}$ fluoxetine, while SERT binding was defined with $50 \mathrm{pM}\left[{ }^{125} \mathrm{I}\right]$ RTI-55 in the presence of $1 \mu \mathrm{M}$ mazindol. Nonspecific binding was determined with $10 \mu \mathrm{M}$ GBR 12909 or $10 \mu \mathrm{M}$ fluoxetine, respectively. Following incubation for $1 \mathrm{~h}$ at room temperature, slides were washed $(1 \times 1 \mathrm{~min}$, then $2 \times 20 \mathrm{~min})$ in icecold buffer, followed by one dip in ice-cold distilled water 
and dried under a gentle stream of cool air. Slides were stored overnight in a desiccator, and then apposed for $6 \mathrm{~h}$ to Kodak X-OMAT AR film in the presence of standard microscales. Autoradiographs were developed using Kodak D-19 developer and fixed with Ilford Hypam Rapid Fixer.

5- $\mathrm{HT}_{1 \mathrm{~A}}$ and $5-\mathrm{HT}_{1 B}$ receptors. Binding to $5-\mathrm{HT}_{1 \mathrm{~A}}$ and $5-\mathrm{HT}_{1 \mathrm{~B}}$ receptors by $\left[{ }^{125} \mathrm{I}\right]$ cyanopindolol was performed with an adaptation of published procedures (Offord et al, 1988; Sexton et al, 1999). In brief, sections were preincubated for $15 \mathrm{~min}$ in ice-cold Tris/HCl buffer $(50 \mathrm{mM}$ Tris, $2.5 \mathrm{mM} \mathrm{MgCl}, 150 \mathrm{mM} \mathrm{NaCl}, \mathrm{pH} 7.4)$ containing $10 \mu \mathrm{M}$ pargyline and $20 \mu \mathrm{M}$ isoprenaline (to prevent binding to $\beta$ adrenoceptors). Slides were then transferred to the incubation buffer containing $30 \mathrm{pM}\left[{ }^{125} \mathrm{I}\right]$ cyanopindolol alone (total) or with the addition of $300 \mathrm{nM}$ CP $93129\left(5-\mathrm{HT}_{1 \mathrm{~B}}\right.$ agonist, to define $5-\mathrm{HT}_{1 \mathrm{~A}}$ binding), $10 \mu \mathrm{M}$ 8-OH-DPAT (5$\mathrm{HT}_{1 \mathrm{~A}}$ agonist, to define $5-\mathrm{HT}_{1 \mathrm{~B}}$ binding), or $20 \mu \mathrm{M} \mathrm{5- \textrm {HT }}$ (nonspecific binding). Following a $2 \mathrm{~h}$ incubation at room temperature, slides were washed $(2 \times 1 \mathrm{~min})$ in ice-cold buffer, then dipped in ice-cold distilled water, and dried as above. Slides were apposed to film for 6 days in the presence of standard microscales and processed as above.

5- $\mathrm{HT}_{2 \mathrm{~A} / 2 \mathrm{C}}$ receptors. Binding to $5-\mathrm{HT}_{2 \mathrm{~A} / 2 \mathrm{C}}$ receptors was visualized using $\left[{ }^{125} \mathrm{I}\right]$ DOI as previously described (Compan et al, 1998a,b). Sections were preincubated for $30 \mathrm{~min}$ at $\mathrm{RT}$ in a Tris/ $\mathrm{HCl}$ buffer $\left(50 \mathrm{mM}\right.$ Tris, $4 \mathrm{mM} \mathrm{CaCl}_{2}, 0.1 \%$ ascorbate, $\mathrm{pH} 7.4$ ) containing $0.1 \%$ bovine serum albumin. Slides were then incubated at room temperature for $1 \mathrm{~h}$ in $0.1 \mathrm{nM}\left[{ }^{125} \mathrm{I}\right] \mathrm{DOI}$ in the presence or absence of $100 \mu \mathrm{M}$ unlabeled DOI to determine nonspecific binding. Slides were then washed $(2 \times 10 \mathrm{~min})$ in ice-cold buffer, dipped in ice-cold distilled water, and dried as above. Slides were apposed to film for 6 days in the presence of standard microscales and processed as above.

Image analysis. Autoradiographic images were captured and analyzed using the Scion Image Analysis Program (v. 1.62, Scion Corporation, USA, PC version of NIH Image). The density of binding was calculated by converting the optical density of the image to $\mathrm{dpm} / \mathrm{mm}^{2}$ with the aid of a standard curve generated with calibrated microscales, as previously described (Chen and Lawrence, 2000). Individual brain nuclei were identified with reference to a stereotaxic atlas (Paxinos and Watson, 1997).

Statistics. Statistical analyses of data from the two anxiety tests, the HPLC assays, and the binding assays were achieved by comparing MDMA and vehicle groups using one-way ANOVA followed by Fisher's PLSD post hoc tests. The significance level for all statistical tests was set at $P<0.05$.

\section{RESULTS}

\section{Social Interaction test}

The results of the social interaction tests conducted 10 weeks post-MDMA are shown in Table 1. There was an
Table I Results from the Social Interaction Test Conducted 10 Weeks Post-MDMA

\begin{tabular}{lcc}
\hline Group & $\begin{array}{c}\text { Time in social } \\
\text { interaction (s) }\end{array}$ & $\begin{array}{c}\text { Number of } \\
\text { interactions (n) }\end{array}$ \\
\hline Vehicle & $120.63(8.05)$ & $56.25(3.27)$ \\
Low MDMA & $72.98(4.03)^{\mathrm{a}}$ & $47.00(3.42)$ \\
High MDMA & $56.31(4.85)^{\mathrm{a}, \mathrm{b}}$ & $42.67(2.28)^{\mathrm{a}}$ \\
\hline
\end{tabular}

Data represent mean (SEM) for $n=12$ social interaction tests per group.

${ }^{a} P<0.05$ relative to vehicle group.

${ }^{\mathrm{b}} \mathrm{P}<0.05$ relative to low-MDMA group.

Table 2 Results from the Emergence Test Conducted II Weeks Post-MDMA

\begin{tabular}{lccc}
\hline Group & $\begin{array}{c}\text { Emergence } \\
\text { latency (s) }\end{array}$ & $\begin{array}{c}\text { Time in open } \\
\text { field (s) }\end{array}$ & $\begin{array}{c}\text { Risk } \\
\text { assessment (s) }\end{array}$ \\
\hline Vehicle & $45.46(4.96)$ & $73.43(8.82)$ & $9.00(0.61)$ \\
Low MDMA & $91.03(11.90)^{\mathrm{a}}$ & $63.16(10.92)$ & $8.83(0.86)$ \\
High MDMA & $1 \mid 8.61(18.88)^{\mathrm{a}}$ & $52.65(10.24)$ & $9.08(0.61)$ \\
\hline
\end{tabular}

Data represent mean (SEM) for $n=12$ per group.

Maximum emergence latency $=300 \mathrm{~s}$ due to $5 \mathrm{~min}$ test.

${ }^{\mathrm{a}} \mathrm{P}<0.05$ relative to vehicle group.

overall effect of group on social interaction time $\left(\mathrm{F}_{2,33}=31.80, P<0.001\right)$ and on the total number of interactions $\left(\mathrm{F}_{2,33}=5.03, P<0.05\right)$. Post hoc tests showed that rats in the low- and high-dose MDMA treatment groups spent significantly less time in social interaction than controls. Rats in the high-dose MDMA group also showed a significantly lower total number of interactions than controls.

\section{Emergence Test}

The results of the emergence test conduced 11 weeks postMDMA are shown in Table 2. There was an overall effect of group on emergence latency $\left(\mathrm{F}_{2,33}=7.80, P<0.01\right)$. Post hoc tests showed that rats in both the low- and high-dose MDMA treatment groups took longer to emerge in the open field than controls. No significant differences were observed in open-field time or risk assessment.

\section{Neurotransmitter Levels}

The results of HPLC analysis of neurotransmitter content in key brain regions are shown in Table 3 . There were no significant differences between groups on 5-HT or 5-HIAA levels within the olfactory bulb. However, significant overall group effects on 5-HT and 5-HIAA were obtained in the prefrontal cortex $\left(\mathrm{F}_{2,15}=12.34, P<0.001\right.$ and $\mathrm{F}_{2,15}=10.07$, $P<0.01)$, striatum $\left(\mathrm{F}_{2,15}=5.69, P<0.05\right.$ and $\mathrm{F}_{2,15}=13.57$, $P<0.001)$, hippocampus $\left(\mathrm{F}_{2,15}=3.99, \quad P<0.05 \quad\right.$ and $\left.\mathrm{F}_{2,15}=6.25, P<0.05\right)$, and amygdala $\left(\mathrm{F}_{2,15}=6.22, P<0.05\right.$ and $\left.\mathrm{F}_{2,15}=6.39, P<0.05\right)$, Rats in the high-dose MDMA group showed significantly lower levels of 5-HT and 5HIAA than rats in either the vehicle or low-dose MDMA groups in all four of these regions. The low-dose MDMA group and vehicle group did not differ significantly in any measures. 
Table 3 Results of HPLC Analysis in Five Brain Areas Conducted 3 Months Post-MDMA

\begin{tabular}{|c|c|c|c|c|}
\hline Region & Treatment & 5-HT & 5-HIAA & DA \\
\hline & Low MDMA & | 53.3 (24.8) & $79.0(\mid 1.0)$ & $97.2(14.8)$ \\
\hline \multirow{2}{*}{ Prefrontal cortex } & Low MDMA & $489.6(37.3)$ & $173.9(12.8)$ & $369.0(70.7)$ \\
\hline & High MDMA & $353.1(15.4)^{a, b}$ & | $8.6(4.9)^{a, b}$ & $288.0(142.9)$ \\
\hline Striatum & Vehicle & $522.2(41.6)$ & $350.0(16.0)$ & $7546.5(372.5)$ \\
\hline \multirow[t]{3}{*}{ Hippocampus } & Vehicle & $592.3(15.3)$ & $407.5(35.4)$ & $78.9(23.3)$ \\
\hline & Low MDMA & $568.2(25.5)$ & $389.5(19.7)$ & $52.8(14.9)$ \\
\hline & High MDMA & $485.3(15.0)^{a, b}$ & $259.2(26.2)^{a, b}$ & $62.1(19.8)$ \\
\hline \multirow[t]{3}{*}{ Amygdala } & Vehicle & $880.4(50.2)$ & $174.8(11.1)$ & $235.3(77.6)$ \\
\hline & Low MDMA & $897.8(53.0)$ & $160.4(13.0)$ & $180.4(19.5)$ \\
\hline & High MDMA & $689.6(54.8)^{a, b}$ & $120.1(12.4)^{a, b}$ & $208.9(45.9)$ \\
\hline
\end{tabular}

Data are mean (SEM) for $n=6$ per group.

Data are in wt ng/g tissue.

${ }^{a} P<0.05$ relative to vehicle group.

${ }^{\mathrm{b}} \mathrm{P}<0.05$ relative to Low MDMA group.

Table 4 Dopamine and Serotonin Transporter Densities 3 Months Post-MDMA

\begin{tabular}{|c|c|c|c|}
\hline & Vehicle & Low MDMA & High MDMA \\
\hline Caudate-putamen & | 45.06 (6.66) & | 39.85 (5.07) & | 39.39 (7.55) \\
\hline Nucleus accumbens & $151.98(7.04)$ & | $39.73(5.26)$ & $138.10(6.39)$ \\
\hline \multicolumn{4}{|l|}{ SERT } \\
\hline Caudate-putamen & $41.93(4.59)$ & $35.13(3.53)$ & $36.00(3.37)$ \\
\hline Cingulate cortex & $56.59(3.08)$ & $55.45(3.76)$ & $44.46(2.16)^{a, b}$ \\
\hline Basolateral amygdala & $96.52(6.00)$ & I I 2.14 (5.85) & $95.23(5.30)^{b}$ \\
\hline Central amygdaloid nucleus & $58.94(3.59)$ & $58.7 \mid(2.3 \mid)$ & $48.39(5.36)$ \\
\hline Medial amygdaloid nucleus & $63.53(2.59)$ & $65.33(2.26)$ & $58.05(3.22)$ \\
\hline Posterolateral cortical amygdaloid nucleus & $81.06(6.00)$ & $85.48(4.98)$ & $61.27(8.68)^{b}$ \\
\hline Piriform cortex & $40.31(4.72)$ & $57.12(7.22)^{\mathrm{a}}$ & $33.90(2.66)^{b}$ \\
\hline Lateral thalamic nuclei & $90.49(5.67)$ & $82.44(5.56)$ & $43.51(5.07)^{a, b}$ \\
\hline Zona incerta & $62.31(9.02)$ & $76.82(4.38)$ & $71.01(2.20)$ \\
\hline Entorhinal cortex & $55.73(4.59)$ & $62.87(2.01)$ & $26.88(4.32)^{a, b}$ \\
\hline Medial raphe & | 12.88 (4.08) & I $18.03(6.4 \mid)$ & | $17.79(2.72)$ \\
\hline Dorsal raphe & $127.56(14.62)$ & $|20.8|(9.60)$ & $119.62(11.17)$ \\
\hline
\end{tabular}

Data are mean (SEM) for $n=6$ per group.

Units of measurement are $\mathrm{dpm} / \mathrm{mm}^{2}$.

${ }^{\text {a }} P<0.05$ relative to vehicle group.

${ }^{\mathrm{b}} \mathrm{P}<0.05$ relative to Low MDMA group.

There were no significant differences between groups in dopamine content in any of the brain regions examined.

\section{DAT Density}

Quantification of $\left[{ }^{125} \mathrm{I}\right]$ RTI-55 binding to DAT sites revealed no significant effects of either high- or low-dose MDMA treatment (Table 4).

\section{SERT Density}

Representative autoradiograms of SERT binding are shown in Figure 1. In contrast to the DAT binding, quantification of binding to SERT by $\left[{ }^{125} \mathrm{I}\right]$ RTI-55 revealed several differences between groups (Table 4). The low-dose MDMA group differed from controls in three brain regions, having significantly lower SERT density in the medial hypothalamus but increased 

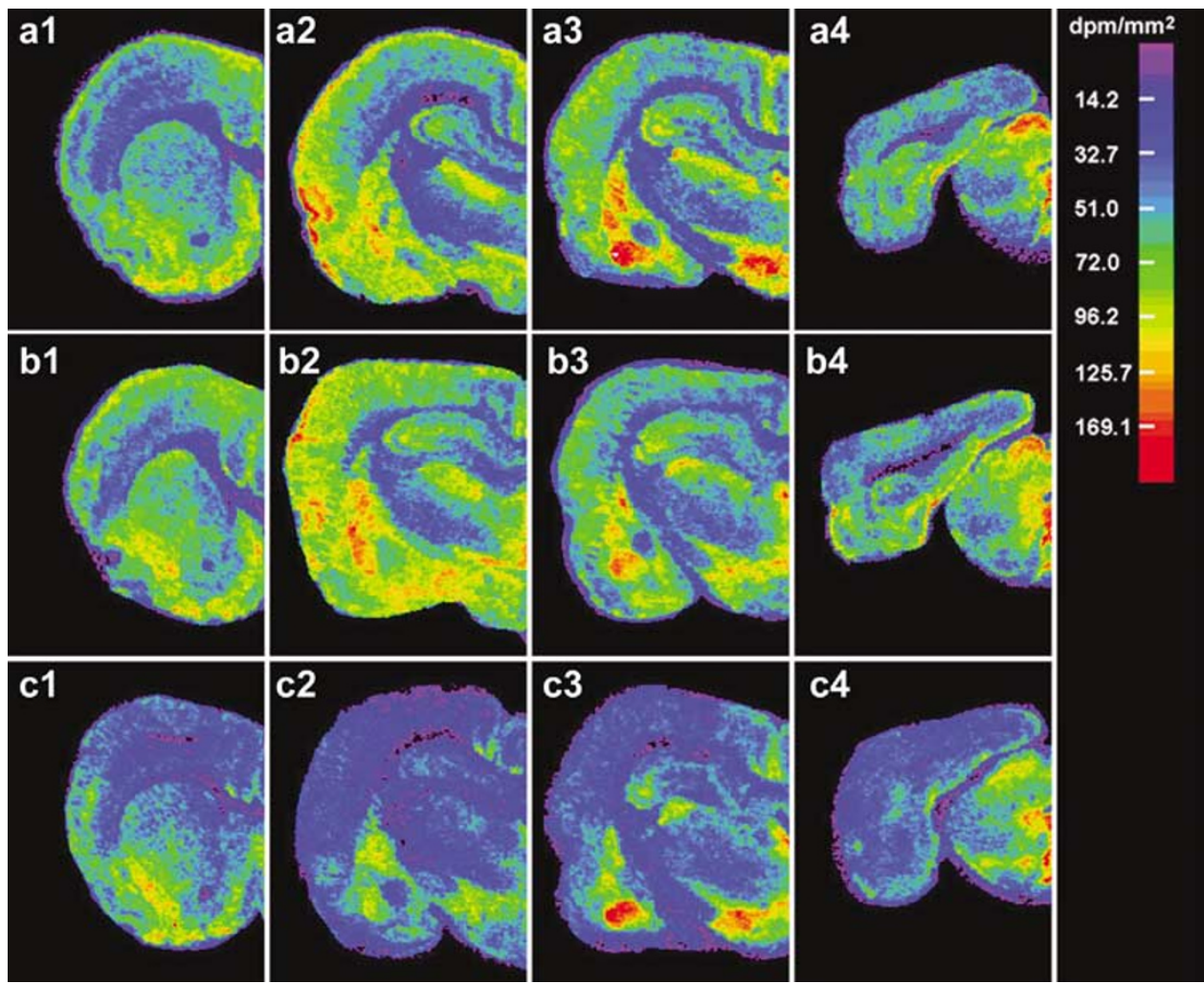

Figure I Representative autoradiograms demonstrating [ $\left.{ }^{125} \mathrm{l}\right]$ RTI-55 binding to SERT of rats in the vehicle (a I-a4, top row), low-dose MDMA (b I-b4, middle row) and high-dose MDMA ( $\mathrm{cl}-\mathrm{c} 4$, bottom row) groups at the level of bregma + 1.2 (far left column), bregma -2.30 (inner left column), bregma -3.60 (inner right column), and bregma -8.00 (far right column). See Table 4 for quantitative analysis of binding data.

SERT density in the piriform cortex and perirhinal/ entorhinal cortex.

The high-dose MDMA group had lower SERT density than controls in nearly every brain region examined. This effect reached statistical significance in several brain regions including the cingulate cortex, hippocampus, entorhinal cortex, medial hypothalamic area, and the medial and lateral thalamic nuclei (Table 4). The high-dose MDMA group also had lower SERT density than the low-dose MDMA group in most brain regions. This difference was statistically significant in the lateral septum, cingulate cortex, basolateral amygdala, cortical amygdaloid nucleus, piriform cortex, perirhinal cortex, medial and lateral thalamic nuclei, and entorhinal cortex (Table 4).

\section{5-HT $1 \mathrm{~A}$ Receptor Density}

The results for $5-\mathrm{HT}_{1 \mathrm{~A}}$ receptor binding are shown in Table 5. There were no significant differences in binding to $5-\mathrm{HT}_{1 \mathrm{~A}}$ receptors between groups in any brain region examined.

\section{5-HT ${ }_{1 \mathrm{~B}}$ Receptor Density}

Representative autoradiograms of $5-\mathrm{HT}_{1 \mathrm{~B}}$ binding are shown in Figure 2, and the densitometric data are presented in Table 6. The low-dose MDMA group showed a significantly lower density of $5-\mathrm{HT}_{1 \mathrm{~B}}$ binding than controls in three brain regions: the globus pallidus, the hippocampus, and the medial thalamic nuclei (Table 6).
Table 5 5-HT IA Receptor Density 3 Months Post-MDMA

\begin{tabular}{lccc}
\hline & Vehicle & Low MDMA & High MDMA \\
\hline Lateral septum & $1.28(0.11)$ & $1.44(0.07)$ & $1.62(0.16)$ \\
Cingulate cortex & $0.55(0.19)$ & $0.66(0.13)$ & $0.35(0.19)$ \\
Insular cortex & $0.64(0.22)$ & $0.69(0.10)$ & $0.65(0.19)$ \\
Piriform cortex & $0.55(0.06)$ & $0.69(0.11)$ & $0.89(0.32)$ \\
Retrosplenial cortex & $0.57(0.23)$ & $0.33(0.11)$ & $0.32(0.16)$ \\
Hippocampus (all) & $1.37(0.14)$ & $1.15(0.14)$ & $1.26(0.08)$ \\
Hippocampus (CAI) & $1.53(0.15)$ & $1.35(0.13)$ & $1.46(0.09)$ \\
Medial hypothalamic area & $0.59(0.07)$ & $0.79(0.15)$ & $0.84(0.18)$ \\
Lateral thalamic nuclei & $0.33(0.12)$ & $0.44(0.15)$ & $0.61(0.23)$ \\
Dorsal raphe & $1.60(0.32)$ & $1.41(0.24)$ & $1.80(0.24)$ \\
\hline
\end{tabular}

Data are mean (SEM) for $n=6$ per group.

Units of measurement are $\mathrm{dpm} / \mathrm{mm}^{2}$.

The high-dose MDMA group showed lower density of 5$\mathrm{HT}_{1 \mathrm{~B}}$ receptors in the globus pallidus, insular cortex and medial thalamus but higher density in the nucleus accumbens. The high-dose MDMA group also showed significantly higher density than the low-dose MDMA group in the lateral septum.

\section{5-HT $2 \mathrm{~A} / 2 \mathrm{C}$ Receptor Density}

Representative autoradiograms of $5-\mathrm{HT}_{2 \mathrm{~A} / 2 \mathrm{C}}$ binding are shown in Figure 3, and the densitometric data are presented in Table 7. The low-dose MDMA group showed a lower density of $5-\mathrm{HT}_{2 \mathrm{~A} / 2 \mathrm{C}}$ receptor binding than controls in most 

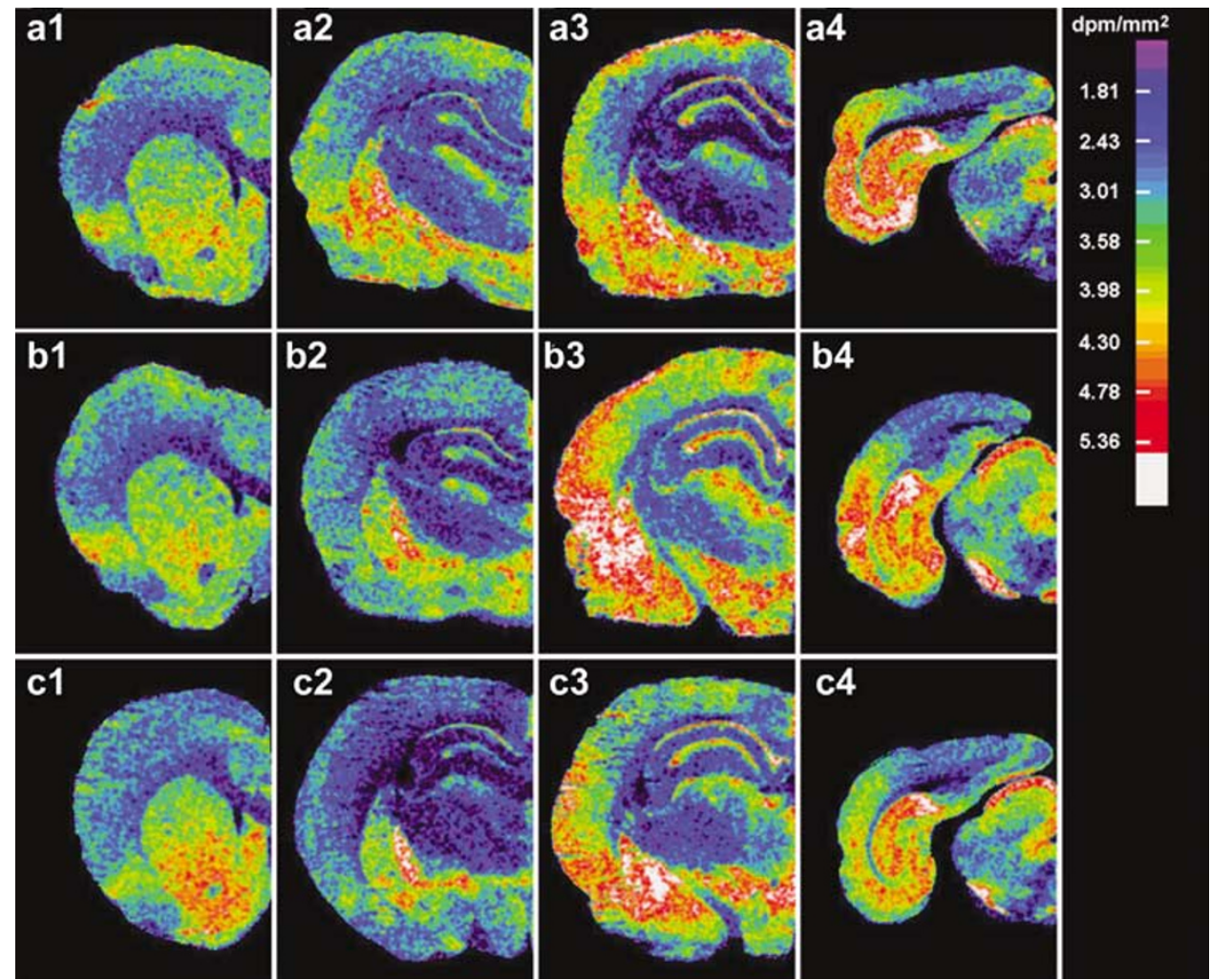

Figure 2 Representative autoradiograms demonstrating [ $\left.{ }^{125} \mathrm{I}\right]$ cyanopindolol binding to $5-\mathrm{HT}_{\mathrm{IB}}$ receptors of rats in the vehicle (a I-a4, top row), low-dose MDMA (bl-b4, middle row) and high-dose MDMA ( $\mathrm{cl}-\mathrm{c} 4$, bottom row) groups at the level of bregma +1.2 (far left column), bregma -2.30 (inner left column), bregma -3.60 (inner right column), and bregma -8.00 (far right column). See Table 6 for quantitative analysis of binding data.

Table 6 5-HT ।B Receptor Density 3 Months Post-MDMA

\begin{tabular}{lccc}
\hline & Vehicle & $\begin{array}{c}\text { Low } \\
\text { MDMA }\end{array}$ & $\begin{array}{c}\text { High } \\
\text { MDMA }\end{array}$ \\
\hline Caudate-putamen & $1.55(0.26)$ & $1.23(0.18)$ & $1.47(0.17)$ \\
Nucleus accumbens & $1.70(0.20)$ & $1.88(0.18)$ & $2.37(0.20)^{\mathrm{a}}$ \\
Lateral septum & $2.36(0.37)$ & $2.13(0.15)$ & $2.83(0.23)^{\mathrm{b}}$ \\
Insular cortex & $2.31(0.07)$ & $2.14(0.11)$ & $1.93(0.12)^{\mathrm{a}}$ \\
Cingulate cortex & $1.29(0.40)$ & $1.19(0.34)$ & $1.13(0.19)$ \\
Globus pallidus & $4.27(0.12)$ & $3.76(0.09)^{\mathrm{a}}$ & $3.70(0.08)^{\mathrm{a}}$ \\
Amygdaloid nuclei & $2.50(0.12)$ & $2.21(0.09)$ & $2.39(0.14)$ \\
$\quad$ Medial amygdaloid nucleus & $2.46(0.11)$ & $2.30(0.21)$ & $2.64(0.27)$ \\
Piriform cortex & $2.60(0.10)$ & $2.42(0.07)$ & $2.43(0.10)$ \\
Perirhinal/entorhinal cortical area & $1.83(0.27)$ & $1.94(0.16)$ & $2.19(0.20)$ \\
Retrosplenial cortex & $1.16(0.16)$ & $1.17(0.16)$ & $1.38(0.17)$ \\
Hippocampus & $1.36(0.03)$ & $1.09(0.10)^{\mathrm{a}}$ & $1.19(0.08)$ \\
$\quad$ CAI stratum oriens & $2.85(0.28)$ & $2.44(0.19)$ & $2.61(0.19)$ \\
$\quad$ Dentate gyrus granule layer & $2.61(0.20)$ & $2.15(0.19)$ & $2.20(0.21)$ \\
Medial hypothalamic area & $2.74(0.14)$ & $2.42(0.17)$ & $2.60(0.17)$ \\
Medial thalamic nuclei & $2.52(0.14)$ & $2.08(0.09)^{\mathrm{a}}$ & $2.16(0.12)^{\mathrm{a}}$ \\
Lateral thalamic nuclei & $2.02(0.12)$ & $1.90(0.15)$ & $1.98(0.11)$ \\
Entorhinal cortex & $3.49(0.81)$ & $3.07(0.54)$ & $3.41(0.30)$ \\
Dorsal raphe & $3.10(0.74)$ & $2.75(0.43)$ & $3.11(0.37)$ \\
\hline
\end{tabular}

Data are mean (SEM) for $n=6$ per group.

Units of measurement are $\mathrm{dpm} / \mathrm{mm}^{2}$.

${ }^{a} P<0.05$ relative to vehicle group.

${ }^{\mathrm{b}} \mathrm{P}<0.05$ relative to Low MDMA group.

brain regions. However, the effect only reached statistical significance in the piriform cortex.

The high-dose MDMA group showed dramatically lower $5-\mathrm{HT}_{2 \mathrm{~A} / 2 \mathrm{C}}$ binding in nearly every brain region examined.
The effect reached statistical significance in several brain regions, including the caudate-putamen, insular cortex, cingulate cortex, lateral septum, frontal cortex, and entorhinal cortex. In addition, the low- and high-dose MDMA groups differed significantly in binding density in many regions, including the caudate-putamen, lateral septum, medial hypothalamus, medial and lateral thalamic nuclei, and entorhinal cortex.

\section{DISCUSSION}

\section{Behavioral Changes and 5-HT Depletion}

The behavioral results obtained confirm previous reports from our laboratory that brief exposure to MDMA leads to a long-term increase in anxiety-like behavior in Wistar rats tested in the social interaction and emergence tests weeks or months after drug administration (Gurtman et al, 2002; Morley et al, 2001). Importantly, anxiogenic effects of MDMA were evident even in rats exposed to a relatively low dose of MDMA $(2 \times 5 \mathrm{mg} / \mathrm{kg}) 3$ months previously, specifically confirming the results obtained by Morley et al (2001) using an identical treatment regime. Rats given the high-dose regime of MDMA showed an even greater anxiogenic response, in agreement with our previous findings (Morley et al, 2001), but in rats given the lower dose regime the anxiogenic response was nonetheless robust. The long-term increases in anxiety seen in rats following MDMA is in agreement with numerous recent reports of elevated anxiety in human MDMA users 

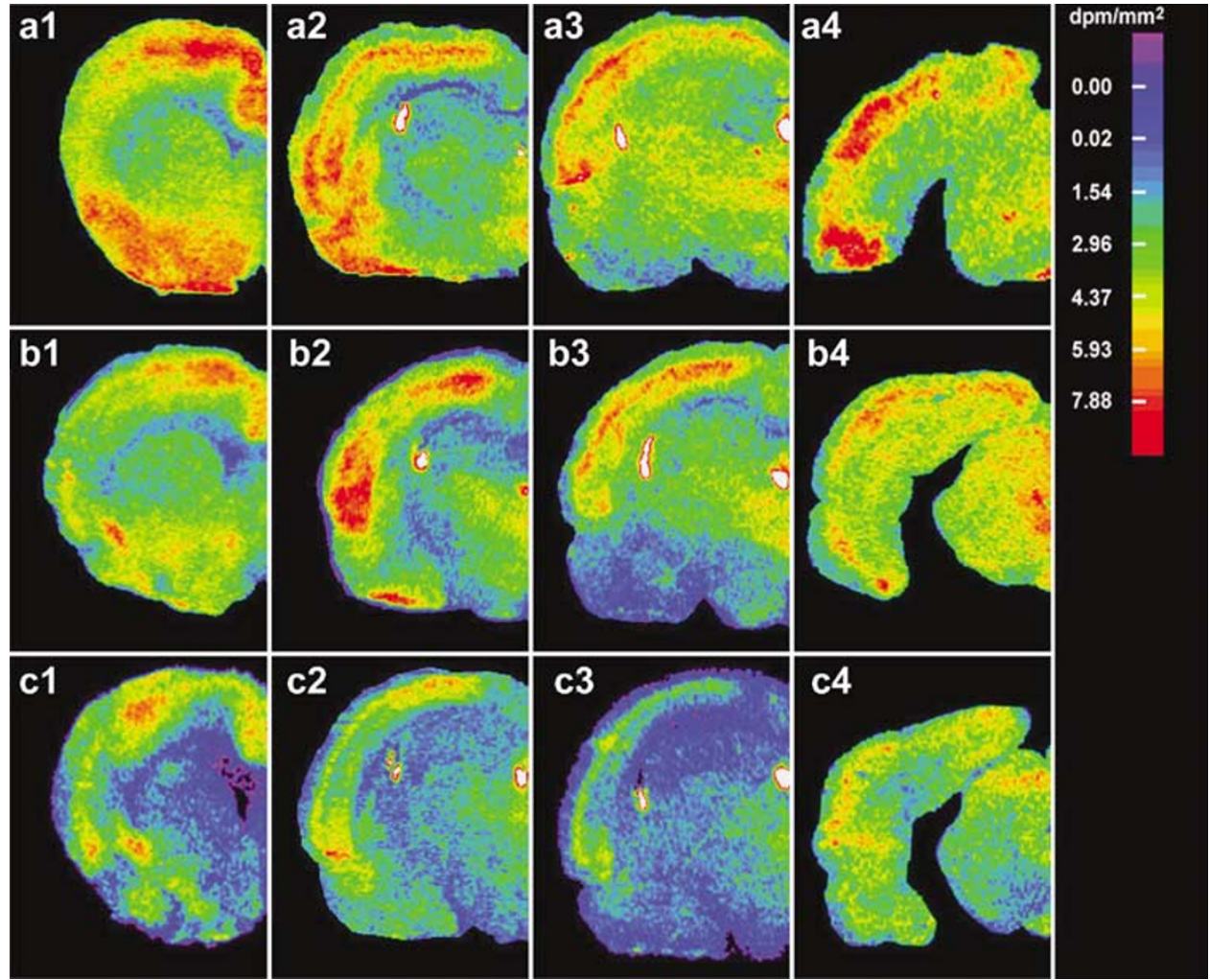

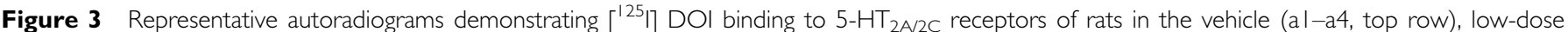
MDMA (b I-b4, middle row), and high-dose MDMA ( $\mathrm{cl}-\mathrm{c} 4$, bottom row) groups at the level of bregma +1.2 (far left column), bregma -2.30 (inner left column), bregma -3.60 (inner right column), and bregma -8.00 (far right column). See Table 7 for quantitative analysis of binding data.

Table 7 5-HT 2A/2C Receptor Density 3 Months Post-MDMA

\begin{tabular}{lccc}
\hline & Vehicle & $\begin{array}{c}\text { Low } \\
\text { MDMA }\end{array}$ & $\begin{array}{c}\text { High } \\
\text { MDMA }\end{array}$ \\
\hline Caudate-putamen & $3.87(0.60)$ & $3.36(0.39)$ & $1.70(0.62)^{\mathrm{a}, \mathrm{b}}$ \\
Nucleus accumbens & $6.13(0.52)$ & $5.09(0.45)$ & $4.01(0.94)^{\mathrm{a}}$ \\
Lateral septum & $4.22(0.56)$ & $4.26(0.17)$ & $2.31(0.63)^{\mathrm{a}, \mathrm{b}}$ \\
Claustrum & $10.18(1.05)$ & $9.87(0.86)$ & $7.39(1.14)^{\mathrm{a}}$ \\
Insular cortex & $7.91(0.7 \mathrm{I})$ & $7.28(0.4 I)$ & $6.14(0.37)^{\mathrm{a}}$ \\
Cingulate cortex & $6.91(0.73)$ & $5.12(0.61)$ & $3.90(0.86)^{\mathrm{a}}$ \\
Medial amygdaloid nucleus & $4.79(0.52)$ & $4.41(0.14)$ & $3.98(0.54)^{\mathrm{a}}$ \\
Piriform cortex & $5.16(0.29)$ & $3.84(0.29)^{\mathrm{a}}$ & $2.72(0.12)^{\mathrm{a}, \mathrm{b}}$ \\
Perirhinal/entorhinal cortical area & $5.00(0.21)$ & $4.22(0.33)$ & $1.82(0.49)^{\mathrm{a}, \mathrm{b}}$ \\
Medial hypothalamic area & $3.07(0.33)$ & $2.67(0.53)$ & $0.68(0.08)^{\mathrm{a}, \mathrm{b}}$ \\
Medial thalamic nuclei & $3.34(0.82)$ & $3.56(0.90)$ & $0.47(0.13)^{\mathrm{a}, \mathrm{b}}$ \\
Lateral thalamic nuclei & $3.42(0.46)$ & $3.37(0.62)$ & $0.50(0.09)^{\mathrm{a}, \mathrm{b}}$ \\
Entorhinal cortex & $1.79(0.21)$ & $2.14(0.26)$ & $1.04(0.37)^{\mathrm{b}}$ \\
\hline
\end{tabular}

Data are mean (SEM) for $n=6$ per group.

Units of measurement are $\mathrm{dpm} / \mathrm{mm}^{2}$.

a $P<0.05$ relative to vehicle group.

${ }^{\mathrm{b}} \mathrm{P}<0.05$ relative to Low MDMA group.

(Gamma et al, 2000; Parrott et al, 2000; Verkes et al, 2001; Wareing et al, 2000).

Higher-dose MDMA treatment was associated with the expected depletion of 5-HT and 5-HIAA 3 months later, although only a relatively modest depletion of $20-30 \%$ across the various regions was evident. Assessment at earlier time intervals after drug administration may have uncovered a greater 5-HT depletion, since gradual recovery of tissue 5-HT levels in the weeks and months following
MDMA treatment is well established (Fischer et al, 1995; Sabol et al, 1996; Scanzello et al, 1993). Rats given the lowdose MDMA treatment had brain 5-HT and 5-HIAA levels that were indistinguishable from controls, suggesting that 5HT depletion is not necessary for the long-term anxiogenic behavioral profile produced by MDMA. This result agrees with recent findings where long-term reductions in social interaction were seen in Lister rats after MDMA, without significant 5-HT depletion (Fone et al, 2002). This is not to deny that 5-HT depletion may have occurred in the lowdose MDMA group shortly after drug treatment although, notably, at least one previous study has failed to find any 5HT depletion 1 week after rats were given $4 \mathrm{mg} / \mathrm{kg}$ MDMA once daily for 4 days (O'Shea et al, 1998). On balance then, this suggests that minimal or no 5-HT depletion occurred in the low-dose MDMA rats at any stage of the present experiment; however, changes in anxiety levels are clearly apparent.

\section{SERT Binding}

The present study found a clear loss of SERT binding sites in rats given the high-dose MDMA regime, in agreement with numerous previous studies showing 5-HT transporter loss in cortical, striatal, or hippocampal homogenates of rats given MDMA (Battaglia et al, 1987; Boot et al, 2002; Colado et al, 2001, 1995; Harkin et al, 2001; O'Shea et al, 1998; Scanzello et al, 1993). A smaller number of studies have depicted the regional loss of SERT binding following MDMA in brain slices using quantitative autoradiographic 
methods similar to those used here (Battaglia et al, 1991; Boot et al, 2002; Fischer et al, 1995; Lew et al, 1996). Only two of these studies have rigorously quantified regional SERT in MDMA-treated rats, albeit in animals subjected to a much higher dose regime $(20 \mathrm{mg} / \mathrm{kg}$, twice a day for 4 consecutive days) and across different time intervals to those used in the present study (Battaglia et al, 1991; Lew et al, 1996). Nonetheless, our results are in broad agreement with these two previous studies showing that high-dose MDMA causes little loss of SERT binding in the basolateral amygdala, dorsal raphe and medial raphe, considerable loss of binding in cortical, hippocampal, septal and striatal sites, and profound loss of binding in specific thalamic nuclei and more posterior cortical regions (Battaglia et al, 1991; Lew et al, 1996).

Interestingly, in one of the previous studies (Lew et al, 1996). a progressive recovery of SERT binding was noted from 2 to 52 weeks following MDMA exposure, suggesting that the rats in the present study may have shown greater SERT loss at earlier time intervals following MDMA. Lew et al (1996) reported that more posterior cortical regions and lateral thalamic areas showed the least recovery of SERT at 52 weeks, a result that is consistent with the profound loss of SERT evident in the present study in the entorhinal cortex and thalamic nuclei 3 months postMDMA.

The low-dose MDMA treatment in the present study had a much smaller effect on SERT: a significant reduction in binding at the level of the medial hypothalamus and a significant increase in SERT binding in the piriform and perirhinal cortex. The exact significance of the upregulation in these two sites is unclear. Given that both low- and highdose MDMA groups exhibited increased anxiety-like behavior yet only the low-dose MDMA group showed this upregulation of SERT, it is unlikely that they can be linked to the increases in anxiety-like behavior. One previous study has shown that the entorhinal/perirhinal region is uniquely sensitive to chronic antidepressant effects on SERT (Hebert et al, 2001), and future studies may hopefully identify what makes the response of SERT in this region to pharmacological stimuli somewhat atypical.

In contrast, the consonant effects of low- and high-dose MDMA on SERT at the level of the medial hypothalamus suggest this region as a possible target for future investigations of MDMA-induced anxiety. A role for hypothalamic nuclei in determining anxiety in the social interaction, exploration, and predator-based models of anxiety is reasonably well established (Dielenberg et al, 2001; File et al, 1999; Shekhar and Katner, 1995).

\section{DAT Binding}

The failure to find any alteration in DAT binding density after MDMA treatment in the present study is in accord with previous reports in rats (Battaglia et al, 1991, 1987; Lew et al, 1996) and humans (Reneman et al, 2002a; Semple et al, 1999). There was also no significant depletion of tissue dopamine.

A very recent report has indicated a profound loss of DAT sites and other dopaminergic markers in squirrel monkeys and baboons given closely spaced low-dose injections of MDMA (Ricaurte et al, 2002). Thus it is conceivable, although yet to be established, that a dose regime different to that used in the present study might cause long-term alterations in DAT. However, this is unlikely to be the mechanism to explain the increase in anxiety-like behavior seen in the present study after MDMA.

\section{5- $\mathrm{HT}_{1 \mathrm{~A}}$ Receptor Binding}

There was little evidence in the present study of alterations in $5-\mathrm{HT}_{1 \mathrm{~A}}$ receptors in rats given either the low- or highdose MDMA treatment. High receptor density was seen in the septum, hippocampus, and dorsal raphe, as would be expected from previous autoradiographic studies of 5- $\mathrm{HT}_{1 \mathrm{~A}}$ receptor distribution (Verge et al, 1986). This receptor has a demonstrated role in anxiety-like behavior in rodents, with targeted deletion of this receptor having effects on behavior in the elevated plus maze and other rodent anxiety models (Ramboz et al, 1998). This receptor also has a role in MDMA effects, inasmuch as MDMA generalizes to the 5$\mathrm{HT}_{1 \mathrm{~A}}$ agonist 8-OH-DPAT in the drug discrimination paradigm (Glennon and Young, 2000).

The failure of MDMA to have long-term effects in 5- $\mathrm{HT}_{1 \mathrm{~A}}$ receptor density is in partial agreement with reports of no alteration in $5-\mathrm{HT}_{1 \mathrm{~A}}$ binding in the various brain regions following extensive serotonergic lesions with the neurotoxin 5,7-DHT (Compan et al, 1998a; Lawrence et al, 1993). However, our results contrast with one report of increased cortical and hypothalamic and decreased raphe 5- $\mathrm{HT}_{1 \mathrm{~A}}$ density at 7 days following repeated MDMA (Aguirre et al, 1995). The difference in the time course of testing may explain the discrepancy in results here as well as the large difference in doses. In agreement with our results, no differential functional response to the $5-\mathrm{HT}_{1 \mathrm{~A}}$ agonist 8OH-DPAT was evident 30-33 days after neurotoxic MDMA treatment (Granoff and Ashby, 2001; Mechan et al, 2001), although some differences were seen in a different study at 7 days post-treatment (Aguirre et al, 1998). Similarly, repeated pre-exposure to high doses of the $5-\mathrm{HT}_{1 \mathrm{~A}}$ agonist 8-OH-DPAT did not alter the locomotor response to MDMA in rats (Callaway and Geyer, 1992).

A cautionary note should be sounded concerning the relatively insensitive and nonselective nature of the radioligand used here to label 5- $\mathrm{HT}_{1 \mathrm{~A}}$ receptors. Accordingly, unequivocal confirmation of the sensitivity (or lack of) of 5$\mathrm{HT}_{1 \mathrm{~A}}$ receptors towards MDMA treatment awaits further experimentation.

\section{5-HT ${ }_{1 \mathrm{~B}}$ Receptor Binding}

Significant long-term changes in $5-\mathrm{HT}_{1 \mathrm{~B}}$ receptor density were seen after both the low- and high-dose MDMA treatments. An increase in density was seen in the nucleus accumbens and lateral septum of rats given the high-dose MDMA treatment. This agrees with the results of Compan et al (1998b) who found increased $5-\mathrm{HT}_{1 \mathrm{~B}}$ receptor density in the nucleus accumbens of rats 3 weeks after major 5-HT depletion accomplished by intra-raphe microinjection of 5,7-DHT. There is also a report of very transient upregulation of $5-\mathrm{HT}_{1 \mathrm{~B}}$ receptors in the striatum following neurotoxic MDMA treatment (Sexton et al, 1999) or following 5-HT depletion with intraventricular 5,7-DHT (Offord et al, 1988). 
In both the low- and high-dose MDMA groups, significant downregulation of $5-\mathrm{HT}_{1 \mathrm{~B}}$ receptors was seen in the globus pallidus and the midline thalamus, with significant decreases also evident in the hippocampus in the low-dose group and in the insular cortex of the high-dose MDMA group. The $5-\mathrm{HT}_{1 \mathrm{~B}}$ receptor is often thought of as a terminal autoreceptor, so the loss of receptors in these areas may be consistent with a loss of 5-HT terminals, also suggested by the loss of SERT in some of these regions. However, the 5$\mathrm{HT}_{1 \mathrm{~B}}$ receptor also acts as a terminal heteroreceptor in some regions, and such receptors would be thought to be unaffected by 5 -HT depletion.

The $5-\mathrm{HT}_{1 \mathrm{~B}}$ receptor plays a key role in the acute hyperactivity produced by MDMA (Bankson and Cunningham, 2002; Scearce-Levie et al, 1999). Our findings of downregulation of $5-\mathrm{HT}_{1 \mathrm{~B}}$ receptors is in agreement with the findings of a diminished locomotor response to a 5$\mathrm{HT}_{1 \mathrm{~B}}$ receptor agonist in rats pre-exposed to high-dose MDMA treatments (Callaway and Geyer, 1992).

Whether changes in the $5-\mathrm{HT}_{1 \mathrm{~B}}$ receptor might underlie the anxiety-like behavior seen in MDMA-treated rats is uncertain. The consequences of $5-\mathrm{HT}_{1 \mathrm{~B}}$ receptor deletion in mice include an increase in aggressive behavior (Saudou et al, 1994) and, if anything, a decrease in anxiety-like behavior (Malleret et al, 1999; Zhuang et al, 1999). On the other hand, overexpression of $5-\mathrm{HT}_{1 \mathrm{~B}}$ receptors in forebrain regions can increase anxiety-like behavior in rats (Clark et al, 2002), and a higher genetically endowed density of forebrain $5-\mathrm{HT}_{1 \mathrm{~B}}$ receptors was associated with greater anxiety in mice (Clement et al, 1996). It therefore appears that the downregulation of $5-\mathrm{HT}_{1 \mathrm{~B}}$ receptors seen (for the most part) in the present study with MDMA is difficult to reconcile with the increased anxiety produced by the drug.

\section{5- $\mathrm{HT}_{2 \mathrm{~A} / 2 \mathrm{C}}$ Receptor Binding}

The most profound neuronal changes in the present study were seen with the $5-\mathrm{HT}_{2 \mathrm{~A} / 2 \mathrm{C}}$ receptors, with high-dose MDMA treatment causing a dramatic loss of this receptor in the cortex, septum and caudate-putamen, and low-dose MDMA treatment tending to have similar effects in many regions, although only significantly in the piriform cortex.

These results agree with previous findings, which have noted downregulation of $5-\mathrm{HT}_{2 \mathrm{~A}}$ receptors in both human MDMA users and rats given MDMA (Reneman et al, 2002b; Scheffel et al, 1992). However, both of these previous studies have suggested that recovery may occur, with receptor density returned to normal levels in rats within 21 days of MDMA treatment in one study (Scheffel et al, 1992). In the other study, rats given an aggressive dose regime of MDMA ( $10 \mathrm{mg} / \mathrm{kg}$ twice a day for 4 days), which produced near $90 \%$ depletion of $5-\mathrm{HT}$, were associated with downregulation of $5-\mathrm{HT}_{2 \mathrm{~A}}$ receptors at 3 but not 30 days following administration. Indeed, at 30 days following administration, upregulation of $5-\mathrm{HT}_{2 \mathrm{~A}}$ receptors was observed in the frontal cortex. Similar upregulation of 5$\mathrm{HT}_{2 \mathrm{~A}}$ was observed in the occipital cortex of abstinent human MDMA users, and this was interpreted at a compensatory response to serotonergic denervation (Reneman et al, 2000, 2002b). However, an alternative explanation concerns the increased availability to bind due to lack of competition with depleted endogenous 5-HT. It is also notable that in one human study recent users of MDMA (on average 3 weeks since the last tablet) showed significant reductions in $5-\mathrm{HT}_{2 \mathrm{~A}}$ binding in all brain regions examined, more in agreement with the current results (Reneman et al, 2002b). The discrepancy between the current results and those of previous studies may well be a reflection of the more moderate dosing regimes used here, which produced modest or no 5-HT depletion.

The $5-\mathrm{HT}_{2 \mathrm{~A}}$ receptor plays a role in the acute response to MDMA, with 5- $\mathrm{HT}_{2 \mathrm{~A}}$ antagonists reducing the locomotor response to MDMA (Bankson and Cunningham, 2002; Kehne et al, 1996) and MDMA-induced hyperthermia (Mechan et al, 2002; Schmidt et al, 1990). A role for the $5-\mathrm{HT}_{2 \mathrm{C}}$ receptor in acute MDMA effects is also suggested by the fact that a $5-\mathrm{HT}_{2 \mathrm{C}}$ receptor antagonist potentiates MDMA-induced hyperactivity (Bankson and Cunningham, 2002). A diminished endocrine and emotional response to the $5-\mathrm{HT}_{2 \mathrm{C}}$ receptor agonist $\mathrm{mCPP}$ has been reported in human MDMA users (McCann et al, 1999), which is also consistent with downregulation of that receptor with MDMA use.

The magnitude of loss of $5-\mathrm{HT}_{2 \mathrm{~A} / 2 \mathrm{C}}$ receptors in the present study was in line with the effects seen on anxietylike behaviors, with a large, highly significant effect in the high-dose MDMA group and a more modest yet nonetheless significant effect in the low-dose MDMA group. Is it therefore conceivable that changes in one, other, or both of these receptors explain the magnification of anxiety-like behavior seen? Again, the answer to this question is not clear. Drugs acting as antagonists at $5-\mathrm{HT}_{2 \mathrm{C}}$ receptors are clearly anxiolytic (Kennett et al, 1997; Martin et al, 2002) while the anxiolytic effects of 5- $\mathrm{HT}_{2 \mathrm{~A}}$ acting drugs are less certain (Griebel et al, 1997). An anxiolytic action of antagonists at $5-\mathrm{HT}_{2 \mathrm{C}}$ receptors suggests that loss of this receptor with MDMA treatment might have anxiolytic, rather than anxiogenic, effects.

Interestingly however, mutant mice lacking $5-\mathrm{HT}_{2 \mathrm{C}}$ receptors take longer to emerge into a novel open field (Tecott $e t$ al, 1998), similar to the effect observed in MDMAtreated rats tested in the present study. Thus, a role for long-term alterations in $5-\mathrm{HT}_{2 \mathrm{C}}$ receptors in MDMAinduced anxiety cannot be ruled out, although clearly much further work is required to confirm this.

\section{Conclusions}

As a recent commentary has noted (Green and McGregor, 2002), the role of 5-HT systems in anxiety is exceedingly complex, and defies simplistic explanations in terms of a one-to-one correspondence between anxiety and endogenous 5-HT levels. This conclusion is certainly reinforced in the present study, where reliable long-term changes in anxiety-like behavior were seen in rats following low-dose MDMA in the absence of any effects on tissue concentrations of 5-HT.

This raises the important question of the mechanism underlying the long-term anxiogenic effect of low-dose MDMA. Low-dose MDMA-treated rats displayed a variety of 5-HT transporter and receptor-related changes, any, all or none of which may be associated with altered anxiety. These include a reduction of SERT binding in the hypothalamus, decreased $5-\mathrm{HT}_{1 \mathrm{~B}}$ receptor binding in the hippocampus, 
globus pallidus and thalamus, and decreased cortical 5$\mathrm{HT}_{2 \mathrm{~A} / 2 \mathrm{C}}$ binding. Any or all of these changes could conceivably be linked to alterations in anxiety-like behavior.

However, it is important to recognize that receptor binding and tissue monoamine concentrations give insight into only a small subset of the potential mechanisms whereby MDMA may exert a long-term influence on brain and behavior. Other useful avenues of enquiry could examine changes in the efficacy of 5-HT receptor subtypes, changes in the transcription of 5-HT-related receptors, and alterations of basal and stimulated 5-HT within the synapse. The ability of MDMA to alter endocrine function chronically (Forsling et al, 2002) is another avenue through which anxiety may be affected as well as global effects on brain energy metabolism (Darvesh et al, 2002). Thus, it would be premature to conclude that the present study has isolated the mechanism through which MDMA chronically increases anxiety in rats. However, it has provided some interesting clues that can be followed up in future studies.

\section{ACKNOWLEDGEMENTS}

This research was supported by an NH\&MRC grant to Iain S McGregor and Glenn E Hunt. We are grateful to Kirsten Morley and Clint Gurtman for their advice on behavioral test procedures. We thank Darek Figa and Debbie Brookes for their assistance with animal care.

\section{REFERENCES}

Aguirre N, Ballaz S, Lasheras B, Delrio J (1998). MDMA (Ecstasy) enhances $5-\mathrm{HT}_{1 \mathrm{~A}}$ receptor density and 8-OH-DPAT-induced hypothermia - blockade by drugs preventing 5-hydroxytryptamine depletion. Eur J Pharmacol 346: 181-188.

Aguirre N, Galbete JL, Lasheras B, Delrio J (1995). Methylenedioxymethamphetamine induces opposite changes in central preand postsynaptic $5-\mathrm{HT}_{1 \mathrm{~A}}$ receptors in rats. Eur J Pharmacol 281: 101-105.

Bankson MG, Cunningham KA (2002). Pharmacological studies of the acute effects of (+)-3,4-methylenedioxymethamphetamine on locomotor activity: role of $5-\mathrm{HT}_{1 \mathrm{~B} / 1 \mathrm{D}}$ and $5-\mathrm{HT}_{2}$ receptors. Neuropsychopharmacology 26: 40-52.

Battaglia G, Sharkey J, Kuhar MJ, De Souza EB (1991). Neuroanatomic specificity and time course of alterations in rat brain serotonergic pathways induced by MDMA (3,4-methylenedioxymethamphetamine): assessment using quantitative autoradiography. Synapse 8: 249-260.

Battaglia G, Yeh SY, O'Hearn E, Molliver ME, Kuhar MJ, De Souza EB (1987). 3,4-Methylenedioxymethamphetamine and 3,4methylenedioxyamphetamine destroy serotonin terminals in rat brain: quantification of neurodegeneration by measurement of [ $3 \mathrm{~h}$ ]paroxetine-labeled serotonin uptake sites. J Pharmacol Exp Ther 242: 911-916.

Boot BP, McGregor LS, Hall W (2000). MDMA (Ecstasy) neurotoxicity: assessing and communicating the risks. Lancet 355: $1818-1821$.

Boot BP, Mechan AO, McCann UD, Ricaurte G (2002). MDMAand P-chlorophenylalanine-induced reduction in 5-HT concentrations: effects on serotonin transporter densities. Eur Pharmacol 453: 239-244.

Broening HW, Bowyer JF, Slikker W (1995). Age-dependent sensitivity of rats to the long-term effects of the serotonergic neurotoxicant (+/-)-3,4-methylenedioxymethamphetamine (MDMA) correlates with the magnitude of the MDMA-induced thermal response. J Pharmacol Exp Ther 275: 325-333.
Callahan BT, Cord BJ, Ricaurte GA (2001). Long-term impairment of anterograde axonal transport along fiber projection originating in the rostral raphe nuclei after treatment with fenfluramine or methylenedioxymethamphetamine. Synapse 40: 113-121.

Callaway CW, Geyer MA (1992). Tolerance and cross-tolerance to the activating effects of 3,4-methylenedioxymethamphetamine and a 5-hydroxytryptamine ${ }_{1 \mathrm{~B}}$ agonist. J Pharmacol Exp Ther 263 : 318-326.

Chen F, Lawrence AJ (2000). 5-HT transporter sites and 5- $\mathrm{HT}_{1 \mathrm{~A}}$ and $5-\mathrm{HT}_{3}$ receptors in fawn-hooded rats: a quantitative autoradiography study. Alcoholism: Clin Exp Res 24: 1093-1102. Clark MS, Sexton TJ, McClain M, Root D, Kohen R, Neumaier JF (2002). Overexpression of $5-\mathrm{HT}_{1 \mathrm{~B}}$ receptor in dorsal raphe nucleus using herpes simplex virus gene transfer increases anxiety behavior after inescapable stress. J Neurosci 22: $4550-4562$.

Clement Y, Kia KH, Daval G, Verge D (1996). An autoradiographic study of serotonergic receptors in a murine genetic model of anxiety-related behaviors. Brain Res 709: 229-242.

Colado MI, O'Shea E, Esteban B, Green AR (2001). Studies on the neuroprotective effect of the enantiomers of AR-A008055, a compound structurally related to clomethiazole, on MDMA ('Ecstasy')-induced neurodegeneration in rat brain. Psychopharmacology 157: 82-88.

Colado MI, Williams JL, Green AR (1995). The hyperthermic and neurotoxic effects of 'Ecstasy' (MDMA) and 3,4-methylenedioxyamphetamine (MDA) in the Dark Agouti (DA) rat, a model of the CYP2D6 poor metabolizer phenotype. Br J Pharmacol 115: $1281-1289$.

Commins DL, Vosmer G, Virus RM, Woolverton WL, Schuster CR, Seiden LS (1987). Biochemical and histological evidence that methylenedioxymethylamphetamine (MDMA) is toxic to neurons in the rat brain. J Pharmacol Exp Ther 241: 338-345.

Compan V, Segu L, Buhot MC, Daszuta A (1998a). Differential effects of serotonin (5-HT) lesions and synthesis blockade on neuropeptide- $\gamma$ immunoreactivity and $5-\mathrm{HT}_{1 \mathrm{~A}}, 5-\mathrm{HT}_{1 \mathrm{~B} / 1 \mathrm{D}}$ and 5 $\mathrm{HT}_{2 \mathrm{~A} / 2 \mathrm{C}}$ receptor binding sites in the rat cerebral cortex. Brain Res 795: 264-276.

Compan V, Segu L, Buhot MC, Daszuta A (1998b). Selective increases in serotonin $5-\mathrm{HT}_{1 \mathrm{~B} / 1 \mathrm{D}}$ and $5-\mathrm{HT}_{2 \mathrm{~A} / 2 \mathrm{C}}$ binding sites in adult rat basal ganglia following lesions of serotonergic neurons. Brain Res 793: 103-111.

Darvesh AS, Shankaran M, Gudelsky GA (2002). 3,4-Methylenedioxymethamphetamine produces glycogenolysis and increases the extracellular concentration of glucose in the rat brain. $J$ Pharmacol Exp Ther 301: 138-144.

Dielenberg RA, Hunt GE, McGregor IS (2001). 'When a rat smells a cat': the distribution of c-fos expression in the rat brain following exposure to a predatory odor. Neuroscience 104: 1085-1097.

File SE, Gonzalez LE, Gallant R (1999). Role of the dorsomedial hypothalamus in mediating the response to benzodiazepines on trial 2 in the elevated plus-maze test of anxiety. Neuropsychopharmacology 21: 312-320.

Fischer C, Hatzidimitriou G, Wlos J, Katz J, Ricaurte G (1995). Reorganization of ascending 5-HT axon projections in animals previously exposed to the recreational drug (+/-)3,4-methylenedioxymethamphetamine (MDMA, 'Ecstasy'). J Neurosci 15: 5476-5485.

Fitzgerald RL, Blanke RV, Poklis A (1990). Stereoselective pharmacokinetics of 3,4-methylenedioxymethamphetamine in the rat. Chirality 2: 241-248.

Fone KCF, Beckett SRG, Topham IA, Swettenham J, Ball M, Maddocks L (2002). Long-term changes in social interaction and reward following repeated MDMA administration to adolescent rats without accompanying serotonergic neurotoxicity. Psychopharmacology 159: 437-444. 
Forsling ML, Fallon JK, Shah D, Tilbrook GS, Cowan DA, Kicman AT et al (2002). The effect of 3,4-methylenedioxymethamphetamine (MDMA, 'Ecstasy') and its metabolites on neurohypophysial hormone release from the isolated rat hypothalamus. $\mathrm{Br} \mathrm{J}$ Pharmacol 135: 649-656.

Gamma A, Frei E, Lehmann D, Pascual-Marqui RD, Hell D, Vollenweider FX (2000). Mood state and brain electric activity in Ecstasy users. NeuroReport 11: 157-162.

Glennon RA, Young R (2000). MDMA stimulus generalization to the $5-\mathrm{HT}_{1 \mathrm{~A}}$ serotonin agonist 8 -hydroxy-2-(di- $n$-propylamino)tetralin. Pharmacol Biochem Behav 66: 483-488.

Granoff MI, Ashby CR (2001). Effect of the repeated administration of (+I-)-3,4-methylenedioxymethamphetamine on the behavioral response of rats to the $5-\mathrm{HT}_{1 \mathrm{~A}}$ receptor agonist $(+/-)$ 8-hydroxy-(di-n-propylamino)tetralin. Neuropsychobiology 43: $42-48$.

Green AR, McGregor IS (2002). On the long-term increase in anxiety following central serotonin depletion with MDMA ('Ecstasy'). Psychopharmacology 162: 448-450.

Griebel G (1995). 5-Hydroxytryptamine-interacting drugs in animal models of anxiety disorders: more than 30 years of research. Pharmacol Ther 65: 319-395.

Griebel G, Perrault G, Sanger DJ (1997). A comparative study of the effects of selective and non-selective $5-\mathrm{HT}_{2}$ receptor subtype antagonists in rat and mouse models of anxiety. Neuropharmacology 36: 793-802.

Gurtman CG, Morley KC, Li KM, Hunt GE, McGregor IS (2002). Increased anxiety in rats after 3,4-methylenedioxymethamphetamine: association with serotonin depletion. Eur J Pharmacol 446: 89-96.

Harkin A, Connor TJ, Mulrooney J, Kelly JP, Leonard BE (2001). Prior exposure to methylenedioxyamphetamine (MDA) induces serotonergic loss and changes in spontaneous exploratory and amphetamine-induced behaviors in rats. Life Sci 68: 1367-1382.

Hebert C, Habimana A, Elie R, Reader TA (2001). Effects of chronic antidepressant treatments on 5-HT and NA transporters in rat brain: an autoradiographic study. Neurochem Int 38: $63-74$

Jagust WJ, Eberling JL, Biegon A, Taylor SE, Vanbrocklin HF, Jordan S et al (1996). Iodine-123-5-iodo-6-nitroquipazine: SPECT radiotracer to image the serotonin transporter. $\mathrm{J} \mathrm{Nucl}$ Med 37: 1207-1214.

Kehne JH, Ketteler HJ, McCloskey TC, Sullivan CK, Dudley MW, Schmidt CJ (1996). Effects of the selective $5-\mathrm{HT}_{2 \mathrm{~A}}$ receptor antagonist MDL 100,907 on MDMA-induced locomotor stimulation in rats. Neuropsychopharmacology 15: 116-124.

Kennett GA, Wood MD, Bright F, Trail B, Riley G, Holland V et al (1997). SB 242084, a selective and brain penetrant $5-\mathrm{HT}_{2 \mathrm{C}}$ receptor antagonist. Neuropharmacology 36: 609-620.

Kish SJ (2002). How strong is the evidence that brain serotonin neurons are damaged in human users of Ecstasy. Pharmacol Biochem Behav 71: 845-855.

Lawrence JA, Olverman HJ, Shirakawa K, Kelly JS, Butcher SP (1993). Binding of 5- $\mathrm{HT}_{1 \mathrm{~A}}$ receptor and 5-HT transporter ligands in rat cortex and hippocampus following cholinergic and serotonergic lesions. Brain Res 612: 326-329.

Lesch KP, Bengel D, Heils A, Sabol SZ, Greenberg BD, Petri S et al (1996). Association of anxiety-related traits with a polymorphism in the serotonin transporter gene regulatory region. Science 274: 1527-1531.

Lew R, Sabol KE, Chou C, Vosmer GL, Richards J, Seiden LS (1996). Methylenedioxymethamphetamine-induced serotonin deficits are followed by partial recovery over a 52 -week period. PART II: radioligand binding and autoradiography studies. $J$ Pharmacol Exp Ther 276: 855-865.

Malberg JE, Sabol KE, Seiden LS (1996). Co-administration of MDMA with drugs that protect against MDMA neurotoxicity produces different effects on body temperature in the rat. $J$ Pharmacol Exp Ther 278: 258-267.

Malberg JE, Seiden LS (1998). Small changes in ambient temperature cause large changes in 3,4-methylenedioxymethamphetamine (MDMA)-induced serotonin neurotoxicity and core body temperature in the rat. J Neurosci 18: 5086-5094.

Malleret G, Hen R, Guillou JL, Segu L, Buhot MC (1999). 5-HT 1 в receptor knock-out mice exhibit increased exploratory activity and enhanced spatial memory performance in the Morris water maze. J Neurosci 19: 6157-6168.

Martin JR, Ballard TM, Higgins GA (2002). Influence of the 5- $\mathrm{HT}_{2} \mathrm{C}$ receptor antagonist, SB-242084, in tests of anxiety. Pharmacol Biochem Behav 71: 615-625.

McCann UD, Eligulashvili V, Mertl M, Murphy DL, Ricaurte GA (1999). Altered neuroendocrine and behavioral responses to $\mathrm{m}$ chlorophenylpiperazine in 3,4-methylenedioxymethamphetamine (MDMA) users. Psychopharmacology 147: 56-65.

McCann UD, Szabo Z, Scheffel U, Dannals RF, Ricaurte GA (1998). Positron emission tomographic evidence of toxic effect of MDMA (Ecstasy) on brain serotonin neurons in human beings. Lancet 352: 1433-1437.

MeChan AO, Esteban B, O'Shea E, Elliott JM, Colado MI, Green AR (2002). The pharmacology of the acute hyperthermic response that follows administration of 3,4-methylenedioxymethamphetamine (MDMA, 'Ecstasy') to rats. Br J Pharmacol 135: 170-180.

MeChan AO, O'Shea E, Elliott JM, Colado MI, Green AR (2001). A neurotoxic dose of 3,4-methylenedioxymethamphetamine (MDMA; Ecstasy) to rats results in a long term defect in thermoregulation. Psychopharmacology 155: 413-418.

Morgan MJ (2000). Ecstasy (MDMA): a review of its possible persistent psychological effects. Psychopharmacology 152: 230-248.

Morley KC, Gallate JE, Hunt GE, Mallet PE, McGregor IS (2001). Increased anxiety and impaired memory in rats 3 months after administration of 3,4-methylenedioxymethamphetamine ('Ecstasy'). Eur J Pharmacol 433: 91-99.

Offord SJ, Ordway GA, Frazer A (1988). Application of [125i]iodocyanopindolol to measure 5-hydroxytryptamine ${ }_{1 \mathrm{~b}}$ receptors in the brain of the rat. J Pharmacol Exp Ther 244: 144-153.

O'Shea E, Granados R, Esteban B, Colado MI, Green AR (1998). The relationship between the degree of neurodegeneration of rat brain 5-HT nerve terminals and the dose and frequency of administration of MDMA (Ecstasy). Neuropharmacology 37: 919-926.

Parrott AC (2001). Human psychopharmacology of Ecstasy (MDMA): a review of 15 years of empirical research. Hum Psychopharmacol 16: 557-577.

Parrott AC, Sisk E, Turner JJD (2000). Psychobiological problems in heavy 'Ecstasy' (MDMA) polydrug users. Drug Alcohol Depend 60: 105-110.

Paxinos G, Watson C (1997). The Rat Brain In Stereotaxic CoOrdinates, (Compact 3rd edn). Academic Press: Academic Press.

Ramboz S, Oosting R, Amara DA, Kung HF, Blier P, Mendelsohn M et al (1998). Serotonin receptor 1A knockout - an animal model of anxiety-related disorder. Proc Natl Acad Sci 95: 14476-14481.

Rausch JL, Hobby HM, Shendarkar N, Johnson ME, Li J (2001). Fluvoxamine treatment of mixed anxiety and depression: evidence for serotonergically mediated anxiolysis. J Clin Psychopharmacol 21: 139-142.

Reneman L, Booij J, Lavalaye J, De Bruin K, Reitsma JB, Gunning B et al (2002a). Use of amphetamine by recreational users of Ecstasy (MDMA) is associated with reduced striatal dopamine transporter densities: a [23i]beta-CIT SPECT study-preliminary report. Psychopharmacology 159: 335-340.

Reneman L, Booij J, Schmand B, Van Den Brink W, Gunning B (2000). Memory disturbances in 'Ecstasy' users are correlated with an altered brain serotonin neurotransmission. Psychopharmacology 148: 322-324. 
Reneman L, Endert E, De Bruin K, Lavalaye J, Feenstra MG, De Wolff FA et al (2002b). The acute and chronic effects of MDMA ('Ecstasy') on cortical 5- $\mathrm{HT}_{2 \mathrm{~A}}$ receptors in rat and human brain. Neuropsychopharmacology 26: 387-396.

Ricaurte G, Bryan G, Strauss L, Seiden L, Schuster C (1985). Hallucinogenic amphetamine selectively destroys brain serotonin nerve terminals. Science 229: 986-988.

Ricaurte G, Yuan J, Hatzidimitriou G, Cord BJ, McCann UD (2002). Severe dopaminergic neurotoxicity in primates after a common recreational dose regimen of MDMA ('Ecstasy'). Science 297: 2260-2263.

Sabol KE, Lew R, Richards JB, Vosmer GL, Seiden LS (1996). Methylenedioxymethamphetamine-induced serotonin deficits are followed by partial recovery over a 52 -week period. Part I: synaptosomal uptake and tissue concentrations. J Pharmacol Exp Ther 276: 846-854.

Saudou F, Amara DA, Dierich A, Lemeur M, Ramboz S, Segu L et al (1994). Enhanced aggressive behavior in mice lacking $5-\mathrm{HT}_{1 \mathrm{~B}}$ receptor. Science 265: 1875-1878.

Scallet AC, Lipe GW, Ali SF, Holson RR, Frith CH, Slikker Jr W (1988). Neuropathological evaluation by combined immunohistochemistry and degeneration-specific methods: application to methylenedioxymethamphetamine. Neurotoxicology 9: 529-537.

Scanzello CR, Hatzidimitriou G, Martello AL, Katz JL, Ricaurte GA (1993). Serotonergic recovery after (+/-)3,4-(methylenedioxy) methamphetamine injury: observations in rats. J Pharmacol Exp Ther 264: 1484-1491.

Scearce-Levie K, Viswanathan SS, Hen R (1999). Locomotor response to MDMA is attenuated in knockout mice lacking the 5- $\mathrm{HT}_{1 \mathrm{~B}}$ receptor. Psychopharmacology 141: 154-161.

Scheffel U, Lever JR, Stathis M, Ricaurte GA (1992). Repeated administration of MDMA causes transient down-regulation of serotonin 5- $\mathrm{HT}_{2}$ receptors. Neuropharmacology 31: 881-893.

Scheffel U, Szabo Z, Mathews WB, Finley PA, Dannals RF, Ravert $\mathrm{HT}$ et al (1998). In vivo detection of short- and long-term MDMA neurotoxicity - a positron emission tomography study in the living baboon brain. Synapse 29: 183-192.

Schifano F, Difuria L, Forza C, Minicuci N, Bricolo R (1998). MDMA (Ecstasy) consumption in the context of polydrug abuse - a report on 150 patients. Drug Alcohol Depend 52: 85-90.
Schmidt CJ, Black CK, Abbate GM, Taylor VL (1990). Methylenedioxymethamphetamine-induced hyperthermia and neurotoxicity are independently mediated by $5-\mathrm{HT}_{2}$ receptors. Brain Res 529: 85-90.

Schworer H, Racke K, Kilbinger H (1987). Cholinergic modulation of the release of 5-hydroxytryptamine from the guinea pig ileum. Naunyn-Schmieddebergs Arch Pharmacol 336: $127-132$.

Semple DM, Ebmeier KP, Glabus MF, O'Carroll RE, Johnstone EC (1999). Reduced in vivo binding to the serotonin transporter in the cerebral cortex of MDMA ('Ecstasy') users. Br J Psychiatry 175: 63-69.

Sexton TJ, Mcevoy C, Neumaier JF (1999). 3,4-Methylenedioxymethamphetamine ('Ecstasy') transiently increases striatal 5$\mathrm{HT}_{1 \mathrm{~B}}$ binding sites without altering $5-\mathrm{HT}_{1 \mathrm{~B}}$ MRNA in rat brain. Mol Psychiatry 4: 572-579.

Shekhar A, Katner JS (1995). Dorsomedial hypothalamic GABA regulates anxiety in the social interaction test. Pharmacol Biochem Behav 50: 253-258.

Tecott LH, Logue SF, Wehner JM, Kauer JA (1998). Perturbed dentate gyrus function in serotonin $5-\mathrm{HT}_{2 \mathrm{C}}$ receptor mutant mice. Proc Natl Acad Sci 95: 15026-15031.

Topp L, Hando J, Dillon P, Roche A, Solowij N (1999). Ecstasy use in Australia: patterns of use and associated harm. Drug Alcohol Depend 55: 105-115.

Verge D, Daval G, Marcinkiewicz M, Patey A, El Mestikawy S, Gozlan $\mathrm{H}$ et al (1986). Quantitative autoradiography of multiple 5-HT1 receptor subtypes in the brain of control or 5,7-dihydroxytryptamine-treated rats. $J$ Neurosci 6: 3474-3482.

Verkes RJ, Gijsman HJ, Pieters MSM, Schoemaker RC, De Visser S, Kuijpers $M$ et al (2001). Cognitive performance and serotonergic function in users of Ecstasy. Psychopharmacology 153: 196-202.

Wareing M, Fisk JE, Murphy PN (2000). Working memory deficits in current and previous users of MDMA ('Ecstasy'). Br J Psychol 91: 181-188.

Zhuang XX, Gross C, Santarelli L, Compan V, Trillat AC, Hen R (1999). Altered emotional states in knockout mice lacking $5-\mathrm{HT}_{1 \mathrm{~A}}$ or 5- $\mathrm{HT}_{1 \mathrm{~B}}$ receptors. Neuropsychopharmacology 21: S52-S60. 